\title{
The Impact of Tick-Borne Diseases on the Bone
}

\author{
Imran Farooq ${ }^{1}\left(\mathbb{D}\right.$ and Tara J. Moriarty ${ }^{1,2, *}$ \\ 1 Faculty of Dentistry, University of Toronto, Toronto, ON M5G 1G6, Canada; imran.farooq@mail.utoronto.ca \\ 2 Department of Laboratory Medicine and Pathobiology, Faculty of Medicine, University of Toronto, \\ Toronto, ON M5G 1G6, Canada \\ * Correspondence: tara.moriarty@dentistry.utoronto.ca; Tel.: +1-416-978-6685
}

check for

updates

Citation: Farooq, I.; Moriarty, T.J. The Impact of Tick-Borne Diseases on the Bone. Microorganisms 2021, 9, 663. https://doi.org/10.3390/

microorganisms 9030663

Academic Editor: Pat Nuttall

Received: 28 November 2020

Accepted: 18 March 2021

Published: 23 March 2021

Publisher's Note: MDPI stays neutral with regard to jurisdictional claims in published maps and institutional affiliations.

\section{Copyright: () 2021 by the authors.} Licensee MDPI, Basel, Switzerland. This article is an open access article distributed under the terms and conditions of the Creative Commons Attribution (CC BY) license (https:/ / creativecommons.org/licenses/by/ $4.0 /)$.

\begin{abstract}
Tick-borne infectious diseases can affect many tissues and organs including bone, one of the most multifunctional structures in the human body. There is a scarcity of data regarding the impact of tick-borne pathogens on bone. The aim of this review was to survey existing research literature on this topic. The search was performed using PubMed and Google Scholar search engines. From our search, we were able to find evidence of eight tick-borne diseases (Anaplasmosis, Ehrlichiosis, Babesiosis, Lyme disease, Bourbon virus disease, Colorado tick fever disease, Tick-borne encephalitis, and Crimean-Congo hemorrhagic fever) affecting the bone. Pathological bone effects most commonly associated with tick-borne infections were disruption of bone marrow function and bone loss. Most research to date on the effects of tick-borne pathogen infections on bone has been quite preliminary. Further investigation of this topic is warranted.
\end{abstract}

Keywords: tick; infection; bone; virus; Anaplasma; Ehrlichia; Babesia; Borrelia

\section{Introduction}

A wide range of bacterial, viral, and protozoan pathogens can be transmitted by ticks, which act as vectors transporting pathogens to hosts, including humans [1,2]. These pathogens are responsible for many known human diseases, including those described in Table 1 below.

Table 1. Human diseases caused by tick-borne pathogens.

\begin{tabular}{|c|c|c|}
\hline Bacterial & Viral & Parasitic \\
\hline \multirow{7}{*}{$\begin{array}{c}\text { Anaplasmosis (Anaplasma } \\
\text { phagocytophilum) [3] }\end{array}$} & Nairoviral diseases: & \multirow{11}{*}{$\begin{array}{c}\text { Babesiosis (Babesia microti, } \\
\text { B. divergens, B. duncani, B. } \\
\text { venatorum) [7] }\end{array}$} \\
\hline & Crimean-Congo & \\
\hline & Hemorrhagic Fever & \\
\hline & $\begin{array}{l}\text { (CCHFV) [4]; Nairobi } \\
\text { Shean Disease (NSDV [5]. }\end{array}$ & \\
\hline & Songling Virus Disease & \\
\hline & $(S G L V)[6]$ & \\
\hline & Phenuiviral diseases: & \\
\hline \multirow{4}{*}{$\begin{array}{c}\text { Ehrlichiosis (Ehrlichia chaffeensis, E. } \\
\text { ewingii, E. muris) [8] }\end{array}$} & Heartland Virus Disease & \\
\hline & (HRTV) [9]; Severe Fever & \\
\hline & with Thrombocytopenia & \\
\hline & Syndrome (SFTSV) [10] & \\
\hline Lyme Disease (Borreliella afzelii, $B$. & Orthomyxoviral diseases: & \\
\hline burgdorferi sensu stricto, B. garinii, & Bourbon virus disease & \\
\hline B. mayonii) [11] & $(B R B V)[12]$ & \\
\hline
\end{tabular}


Table 1. Cont.

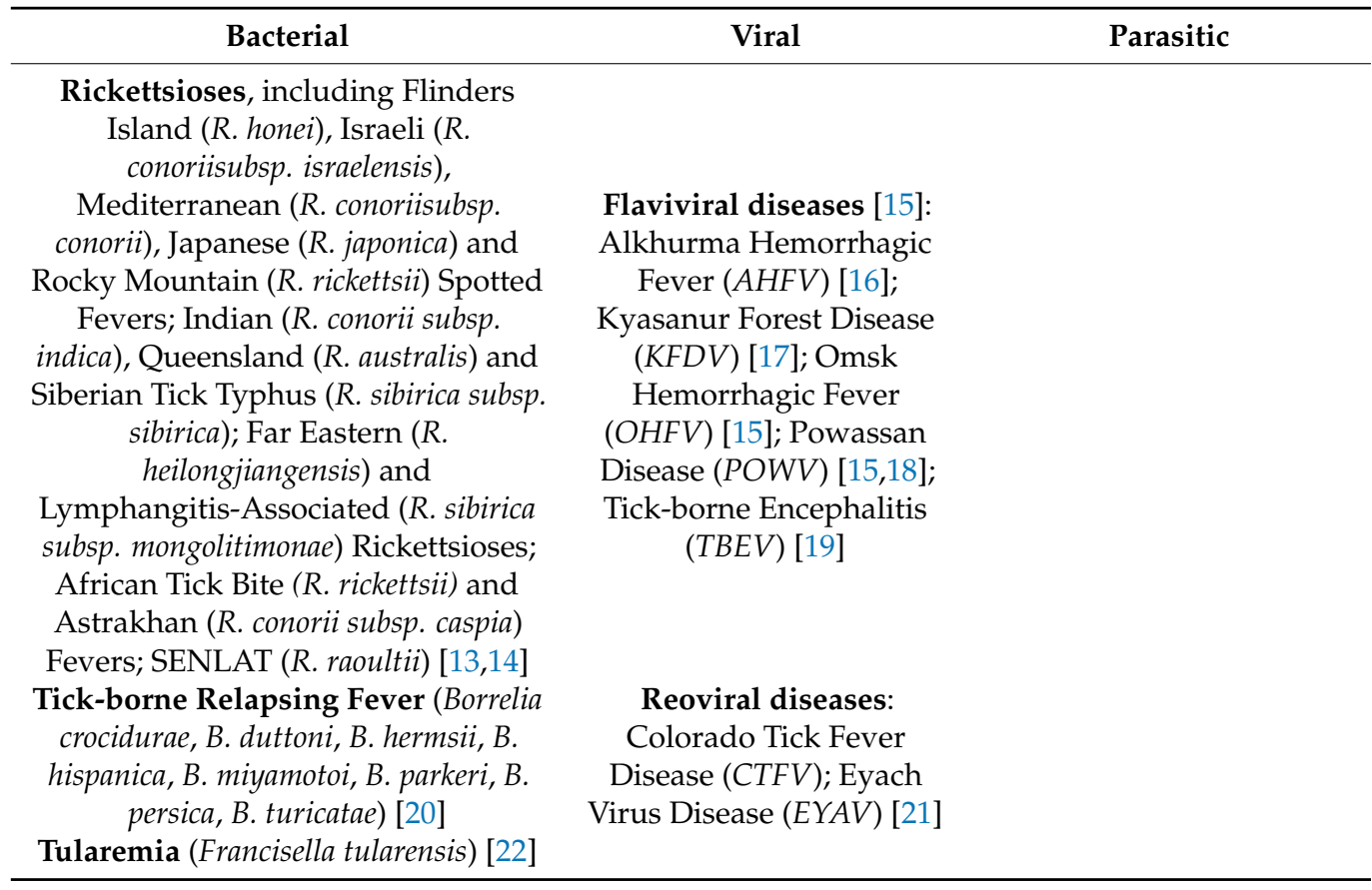

One of the most essential structures in vertebrates is bone, which supports the body, protects vital organs and stores minerals [23]. Bone is a mixture of inorganic content (minerals primarily in the form of hydroxyapatite crystals), organic components such as collagen, cells and proteins, and water [24,25]. There are two major types of bone: (1) cortical (compact) and (2) trabecular (spongy, cancellous or porous). In trabecular bone, the spaces between mineralized bone trabecula are filled with bone marrow and fat tissue (Figure 1). Bone marrow is highly vascularized and innervated and is responsible for the production of red blood cells, granulocytes, platelets, monocytes and lymphocytes [26].

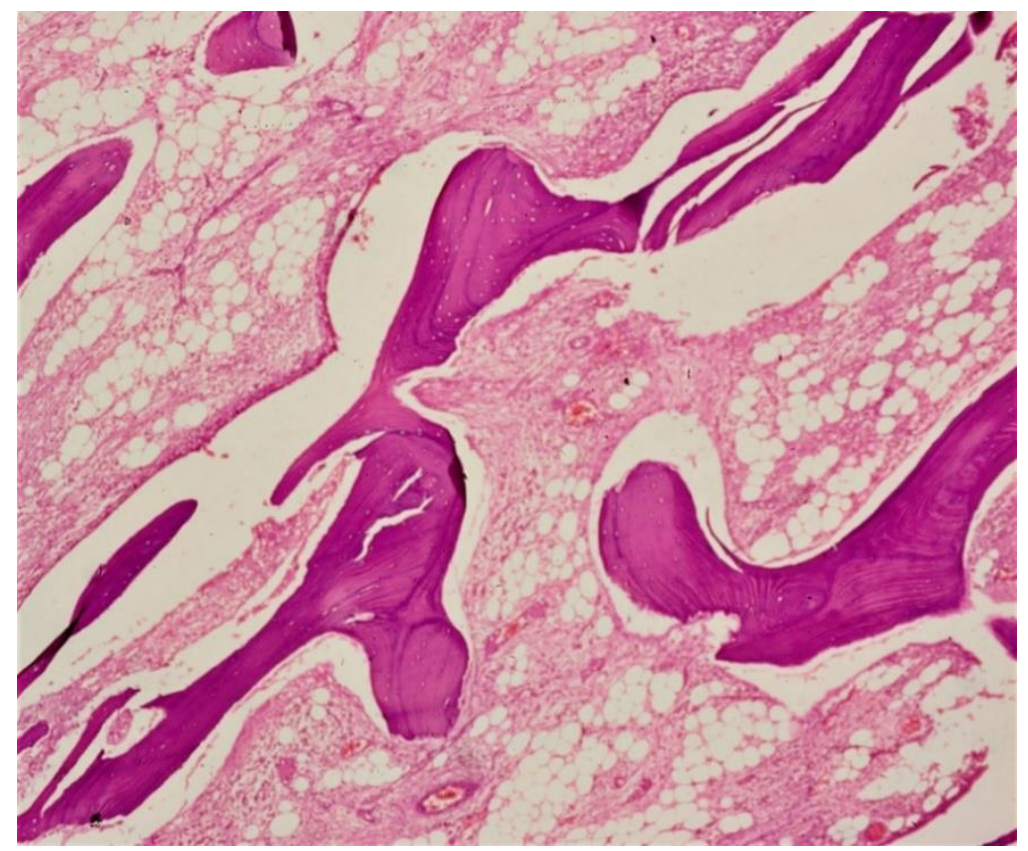

Figure 1. Hematoxylin and eosin ( $\mathrm{H}$ and $\mathrm{E})$ stained decalcified section showing bony trabeculae of spongy bone with marrow spaces and fat tissue. 
Bone in most parts of the body is renewed by a dynamic process called bony remodelling [27], which involves four basic steps: resorption, reversal, formation and resting (Figure 2). Bony remodelling is driven by counterbalancing activities of osteoclasts, which are responsible for bone resorption, and osteoblasts, which are responsible for bone building (apposition) [28].
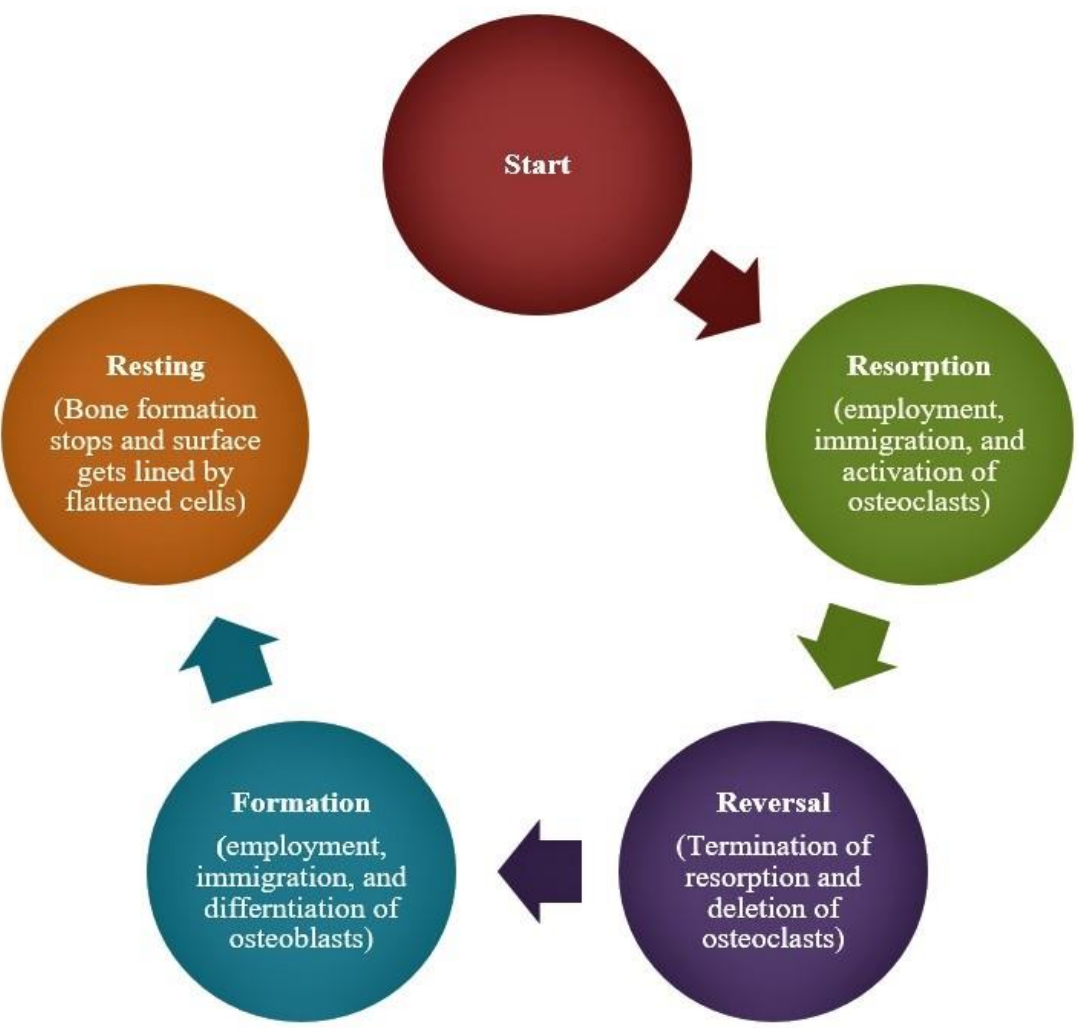

Figure 2. Flow chart depicting sequence of events during bony remodelling process. Adapted from Raggat and Partridge [29].

Bone plays a complex and important role in immune responses, and local and systemic infections can also cause bone pathology [30-32]. Osteoblasts and osteocytes can regulate numbers and differentiation of B-cells and T-cells in bone marrow [33,34], and osteoclasts create the bone marrow cavity required for normal hematopoiesis [35]. Infections and conditions accompanied by systemic immune responses, such as inflammatory bowel disease, can cause bone loss because inflammatory cytokines can stimulate osteoclastogenesis and bone resorption [36]. Microbes also directly colonize bone, as a result of injury, surgery, implanted devices and hematogenous dissemination from more distant infection sites. In some cases, colonization is accompanied by infectious pathologies including bone marrow dysfunction and bone loss.

To the best of our knowledge, the effects of tick-borne infections on bone have not been reviewed previously. We surveyed the primary research literature for studies investigating the changes occurring in the bone structure and function during human tick-borne pathogen infections. We used PubMed and Google Scholar search engines and keywords "tick", "vector", "bone" and the names of individual human tick-borne diseases and pathogens. Conference abstracts and articles published in languages other than English were excluded. These searches retrieved 500+ unique results, of which 132 were finally selected based on their relevance to the investigated topic in this review. Tick-borne diseases associated with human bone phenotypes are listed in Table 2 and described in greater detail below. 
Table 2. Tick-borne diseases with reported human bone phenotypes.

\begin{tabular}{ccc}
\hline Tick-Borne Disease & \multicolumn{3}{c}{ Impact on Bone } \\
\hline & Disrupted Bone Marrow Function & Bone Loss \\
\hline Anaplasmosis & $\sqrt{ }$ & - \\
Ehrlichiosis & $\sqrt{ }$ & - \\
Babesiosis & $\sqrt{ }$ & - \\
Lyme disease & - & - \\
Bourbon virus disease & $\sqrt{ }$ & - \\
Colorado tick fever disease & $\sqrt{ }$ & - \\
Tick-borne encephalitis & $\sqrt{ }$ & - \\
Crimean-Congo Hemorrhagic & $\sqrt{ }$ & \\
Fever & &
\end{tabular}

\section{Anaplasmosis (Formerly Human Granulocytic Ehrlichiosis)}

Anaplasmosis [3] is caused by the Gram-negative intracellular bacterium A. phagocytophilum, which infects myeloid cells (neutrophils, megakaryocytes, mast cells) and endothelial cells [37-39]. A. phagocytophilum and related species can infect humans, cattle, deer, dogs, foxes, horses, wild and laboratory mice and sheep [40-42]. In humans, the most common signs and symptoms include fever, malaise, myalgia, headache, arthralgia, thrombocytopenia, leukopenia and less commonly anemia [3]. Complications can include respiratory illness, organ failure and death. Although A. phagocytophilum appears to typically be transmitted by ticks, transmission has been reported after contact with infected blood [43].

A. phagocytophilum is detected in the bone marrow of sheep, mice, deer, horses, dogs, and humans [40-42,44-48]. Infection in mice and humans often features peripheral cytopenias accompanied by bone marrow abnormalities associated with dyserythropoiesis, dysmegakaryopoiesis impaired red blood cell and platelet regeneration) and hemophagocytic lymphohistiocytosis [41,47-53]. There is some evidence that these cytopenias could result from peripheral processes including extravascular hemolysis [54], but peripheral cytopenias appear to primarily result from dyserythropoiesis and dysmegakaryopoiesis [41,47,48]. The molecular mechanisms underlying bone marrow dysfunction in anaplasmosis are not yet understood. In vitro, bone marrow progenitors belonging to monocytic and granulocytic lineages are prone to infection by A. phagocytophilum [55]. Animal studies suggest that myelosuppressive chemokines produced during anaplasmosis reduce bone marrow proliferation and differentiation [56]. The exposure of bone marrow cells to chemokines (IL-8 and MIP-1) decreases the proliferation and differentiation of myeloid progenitor cells leading to reduced hematopoiesis [57]. Substantial further research is needed to understand the mechanisms of bone marrow suppression and their consequences in disease progression and outcomes of anaplasmosis.

\section{Ehrlichiosis}

Ehrlichiosis is caused by multiple species from the Ehrlichia genus of obligate intracellular bacteria, including E. chaffeensis, E. ewingii and E. muris eauclairensis [58,59]. Ehrlichia mainly infects monocytes and neutrophils in dogs, rodents, and humans $[8,60]$. The signs and symptoms of ehrlichiosis are non-specific, similar to many tick-borne infections and include fever, chills, and a rash [61].

Ehrlichia have been detected in the bone marrow of dogs, cows, mice, and humans [62-65]. Infections in animals and humans feature monocytosis and cytopenias accompanied by abnormal bone marrow function, indicated by dyshematopoiesis and dyserythropoiesis [66-68]. Peripheral cytopenias marked by anemia, thrombocytopenia or neutropenia have been reported in animals and humans [62-68]. Although the mechanism by which ehrlichiosis causes cytopenias is not well established, it is believed that Ehrlichia can invade myeloid cells of the bone marrow, resulting in dyshematopoiesis causing cytopenias [69]. As a compensatory response to the developing cytopenias, an increased number 
of immature megakaryocytes are produced [70], possibly causing thrombocytopenia. Cyotopenias observed in ehrlichiosis could also result from hypocellular bone marrow [70], although the reason for its hypocellularity is not clear. During chronic Ehrlichia infections, cytokine-mediated immune suppression, decreased production of blood cells, and sequestration of erythrocytes can all play their part in decreased erythropoiesis [68]. Bone marrow abnormalities seen in ehrlichiosis could also be caused by the production of type I interferons (IFN $\alpha / \beta)$ that are produced in response to almost all the infections. During ehrlichial infections, IFN $\alpha / \beta$ induces bone marrow loss and impaired hematopoiesis by causing decreased proliferation of hematopoietic stem and progenitor cells [69]. Though an effort has been made to pinpoint the cause of bone marrow suppression during ehrlichiosis, these mechanisms are largely speculative, and further work is needed to determine their exact effects on the bone marrow causing dyshematopoiesis.

\section{Babesiosis}

Microscopic intracellular Babesia parasites cause babesiosis. Babesia species mostly infect erythrocytes in the host, causing haemolytic anemia, which is especially dangerous in older adults [71]. Mild to moderate forms of illness are usually accompanied by fever, fatigue, malaise, headache, and chills [72]. Complications of severe illness include respiratory distress, renal failure, coma, or death [72].

Babesia have been detected in bone marrow of cattle, mice, dogs, and humans [73-77]. Babesia are intraerythrocytic parasites [78] and the most significant bone marrow abnormality associated with babesiosis is dyserythropoiesis, leading to anemia [79]. Thrombocytopenia also occurs in both animals and humans but is a less common presentation than anemia in both species [80-83]. Babesia invasion of erythrocytes can lead to intravascular hemolysis [80]. The mechanisms by which Babesia suppresses bone marrow function are largely unknown.

\section{Lyme Disease}

Members of the B. burgdorferi species complex are extracellular spirochete bacteria that cause Lyme disease or Lyme borreliosis [11]. Early Lyme disease symptoms can include fever, chills, headache, sweating, joint pain, myalgia, swollen lymph nodes and erythema migrans skin rash. Untreated Lyme disease can have complications such as arthritis, endocarditis, and neuroborreliosis [11].

B. burgdorferi has been detected in the bone marrow of dogs, birds, mice and humans [84-87], and bone pain, erosion at articular surfaces, osteomyelitis and osteopenia have been reported [86-97]. B. burgdorferi infection in mice causes trabecular bone loss due to inhibition of bone apposition rather than bone resorption [86]. One plausible reason for this finding could be that $B$. burgdorferi infection causes an upregulation of tumor necrosis factor-alpha (TNF- $\alpha$ ), IL-1, and IL-6 $[98,99]$ that can cause suppression of osteoblastogenesis [100]. The bone infection caused by B. burgdorferi is an emerging area and requires further investigation to shed light on the exact mechanism behind this phenomenon, especially in terms of its effect on osteoblastogenesis.

\section{Bourbon Virus Disease}

Bourbon virus disease is caused by the recently discovered Bourbon virus [101]. Signs and symptoms of this disease resemble those of many other tick-borne diseases and include fever, sweating, headache, fatigue, myalgia and arthralgia [101].

Bourbon virus infection in humans and mice often features peripheral cytopenias including thrombocytopenia, leukopenia and lymphopenia indicating possible bone marrow suppression [101,102]. As Bourbon virus disease has been recently discovered, more investigation is needed to understand its impact on the bone. 


\section{Colorado Tick Fever Disease}

Colorado tick fever virus (CTFV) can infect humans, rodents and some other mammals and is responsible for the rare CTF disease in humans [103-105]. CTF disease signs and symptoms include biphasic fever, chills, headache, fatigue, skin rash and peripheral cytopenias including leukopenia, anemia and thrombocytopenia [106,107].

CTFV can infect and persist in human and murine erythrocytes for extended periods [108]. The prolonged viremia associated with CTFV infection is possibly due to the prolonged persistence of CTFV in intra-erythrocytic locations [109]. CTFV can cause multilineage cytopenias by directly invading and replicating inside the bone marrow CD34+ stem cells [110]. As CD34+ stem cells are important part of the hematopoietic system [111], the replication of CTFV inside these cells is indicative of abnormal hematopoiesis and bone marrow suppression [110]. The CTFV infection can also affect the immature bone marrow cells and this infection can persist through their various stages of maturation [112]. Although various reasons for bone marrow suppression have been hypothesized in the literature, more investigative studies are recommended.

\section{Tick-Borne Encephalitis}

The tick-borne encephalitis (TBE) is caused by the TBE virus (TBEV) [113]. Many patients infected by TBEV remain asymptomatic. Symptomatic patients usually suffer from fever, headaches, body aches, malaise, nausea, and vomiting, with thrombocytopenia and leukopenia seen early in infection in humans, dogs and horses [114-120].

TBE virus has been detected in the bone marrow of animals and humans [121,122], but it is unknown if and how bone marrow infection contributes to peripheral cytopenias.

\section{Crimean-Congo Hemorrhagic Fever}

Crimean-Congo Hemorrhagic Fever (CCHF) is caused by the CCHF virus (CCHFV) [123]. Infection can result in multi-organ failure secondary to cytokine storm and hemorrhage and has a fatality rate ranging between $3 \%$ and $50 \%$ [124]. The most common signs and symptoms of CCHF include sudden fever, chills, and severe migraine-like headaches [125]. Less common symptoms are vomiting and haemorrhages [126].

$\mathrm{CCHFV}$ presence in the bone marrow is not reported in the literature. CCHFV infection features peripheral cytopenias that are marked by thrombocytopenia and leukopenia in animals and humans [127-130]. One fatal feature of CCHFV infection is hemophagocytic syndrome (HPS) that is characterized by excessive bleeding due to cytokine storm [131]. Uncontrolled hypercytokinemia leads to myelosuppression and vascular damage causing multiple organ failure and death [132]. It is not clear if peripheral cytopenias are secondary to bone marrow dysfunction or systemic immune pathologies, and more research is needed on this topic.

\section{Conclusions}

This review concludes that multiple tick-borne diseases can infect and cause pathology in bone and bone marrow. Mechanisms underlying bone pathology in many of these diseases have been under-investigated and further study of this topic is warranted.

Author Contributions: Conceptualization, I.F. and T.J.M.; methodology, I.F. and T.J.M.; investigation, I.F. and T.J.M.; data curation, I.F. and T.J.M.; writing —original draft preparation, I.F.; writing — review and editing, I.F. and T.J.M.; visualization, I.F.; supervision, T.J.M. All authors have read and agreed to the published version of the manuscript.

Funding: This research received no external funding.

Conflicts of Interest: The authors declare no conflict of interest.

\section{References}

1. Rochlin, I.; Toledo, A. Emerging tick-borne pathogens of public health importance: A mini-review. J. Med. Microbiol. 2020, 69, 781-791. [CrossRef] 
2. Rodino, K.G.; Theel, E.S.; Pritt, B.S. Tick-borne diseases in the United States. Clin. Chem. 2020, 66, 537-548. [CrossRef] [PubMed]

3. Bakken, J.S.; Dumler, J.S. Human granulocytic anaplasmosis. Infect. Dis. Clin. N. Am. 2015, 29, 341-355. [CrossRef]

4. Fillâtre, P.; Revest, M.; Tattevin, P. Crimean-Congo hemorrhagic fever: An update. Med. Mal. Infect. 2019, 49, 574-585. [CrossRef]

5. Krasteva, S.; Jara, M.; Frias-De-Diego, A.; Machado, G. Nairobi Sheep Disease Virus: A Historical and Epidemiological Perspective. Front. Vet. Sci. 2020, 7, 419. [CrossRef] [PubMed]

6. Ma, J.; Lv, X.-L.; Zhang, X.; Han, S.Z.; Wang, Z.D.; Li, L.; Sun, H.T.; Ma, L.X.; Cheng, Z.L.; Shao, J.W.; et al. Identification of a new orthocnairovirus associated with human febrile illness in China. Nat. Med. 2021, 27, 434-439. [CrossRef]

7. Krause, P.J. Human babesiosis. Int. J. Parasitol. 2019, 49, 165-174. [CrossRef]

8. Saito, T.B.; Walker, D.H. Ehrlichioses: An Important One Health Opportunity. Vet. Sci. 2016, 3, 20. [CrossRef]

9. Brault, A.C.; Savage, H.M.; Duggal, N.K.; Eisen, R.J.; Staples, J.E. Heartland Virus Epidemiology, Vector Association, and Disease Potential. Viruses 2018, 10, 498. [CrossRef] [PubMed]

10. Bopp, N.E.; Kaiser, J.A.; Strother, A.E.; Barrett, A.D.T.; Beasley, D.W.C.; Benassi, V.; Milligan, G.N.; Preziosi, M.P.; Reece, L.M. Baseline mapping of severe fever with thrombocytopenia syndrome virology, epidemiology and vaccine research and development. NPJ Vaccines 2020, 5, 111. [CrossRef]

11. Steere, A.C.; Strle, F.; Wormser, G.P.; Hu, L.T.; Branda, J.A.; Hovius, J.W.; Li, X.; Mead, P.S. Lyme borreliosis. Nat. Rev. Dis. Primers 2016, 2, 16090. [CrossRef] [PubMed]

12. Madison-Antenucci, S.; Kramer, L.D.; Gebhardt, L.L.; Kauffman, E. Emerging Tick-Borne Diseases. Clin. Microbiol. Rev. 2020, 33, e00083-18. [CrossRef] [PubMed]

13. Sahni, A.; Fang, R.; Sahni, S.K.; Walker, D.H. Pathogenesis of Rickettsial Diseases: Pathogenic and Immune Mechanisms of an Endotheliotropic Infection. Annu. Rev. Pathol. 2019, 14, 127-152. [CrossRef]

14. Piotrowski, M.; Rymaszewska, A. Expansion of Tick-Borne Rickettsioses in the World. Microorganisms 2020, 8, 1906. [CrossRef] [PubMed]

15. Kemenesi, G.; Bányai, K. Tick-Borne Flaviviruses, with a Focus on Powassan Virus. Clin. Microbiol. Rev. 2019, 32, e00106-17. [CrossRef]

16. Bhatia, B.; Fledmann, H.; Marzi, A. Kyasanur Forest Disease and Alkhurma Hemorrhagic Fever Virus-Two Neglected Zoonotic Pathogens. Microorganisms 2020, 8, 1406. [CrossRef]

17. Shah, S.Z.; Jabbar, B.; Ahmed, N.; Rehman, A.; Nasir, H.; Nadeem, S.; Jabbar, I.; Rahman, Z.U.; Azam, S. Epidemiology, Pathogenesis, and Control of a Tick-Borne Disease- Kyasanur Forest Disease: Current Status and Future Directions. Front. Cell. Infect. Microbiol. 2018, 8, 149. [CrossRef]

18. Corrin, T.; Greig, J.; Harding, S.; Young, I.; Mascarenhas, M.; Waddell, L.A. Powassan virus, a scoping review of the global evidence. Zoonoses Public Health 2018, 65, 595-624. [CrossRef]

19. Velay, A.; Paz, M.; Cesbron, M.; Gantner, P.; Solis, M.; Soulier, E.; Argemi, X.; Martinot, M.; Hansmann, Y.; Fafi-Kremer, S. Tick-borne encephalitis virus: Molecular determinants of neuropathogenesis of an emerging pathogen. Crit. Rev. Microbiol. 2019, 45, 472-493. [CrossRef]

20. Talagrand-Reboul, E.; Boyer, P.H.; Bergström, S.; Vial, L.; Boulanger, N. Relapsing Fevers: Neglected Tick-Borne Diseases. Front. Cell. Infect. Microbiol. 2018, 8, 98. [CrossRef]

21. Eisen, R.J.; Kugeler, K.J.; Eisen, L.; Beard, C.B.; Paddock, C.D. Tick-Borne Zoonoses in the United States: Persistent and Emerging Threats to Human Health. ILAR J. 2017, 58, 319-335. [CrossRef]

22. Telford, S.R.; Goethert, H.K. Ecology of Francisella tularensis. Annu. Rev. Entomol. 2020, 65, 351-372. [CrossRef] [PubMed]

23. Su, N.; Yang, J.; Xie, Y.; Du, X.; Chen, H.; Zhou, H.; Chen, L. Bone function, dysfunction and its role in diseases including critical illness. Int. J. Biol. Sci. 2019, 15, 776-787. [CrossRef]

24. Boskey, A.L. Bone composition: Relationship to bone fragility and antiosteoporotic drug effects. Bonekey Rep. 2013, 2, 447. [CrossRef]

25. Feng, X. Chemical and Biochemical Basis of Cell-Bone Matrix Interaction in Health and Disease. Curr. Chem. Biol. 2009, 3, 189-196.

26. Travlos, G.S. Normal structure, function, and histology of the bone marrow. Toxicol. Pathol. 2006, 34, 548-565. [CrossRef] [PubMed]

27. Zaidi, M. Skeletal remodeling in health and disease. Nat. Med. 2007, 13, 791-801. [CrossRef]

28. Rucci, N. Molecular biology of bone remodelling. Clin. Cases Miner. Bone Metab. 2008, 5, 49-56.

29. Raggat, L.J.; Partridge, N.C. Cellular and Molecular Mechanisms of Bone Remodeling. J. Biol. Chem. 2010, 285, 25103-25108. [CrossRef]

30. Oliveira, T.C.; Gomes, M.S.; Gomes, A.C. The crossroads between infection and bone loss. Microorganisms 2020, 8, 1765. [CrossRef] [PubMed]

31. Romanò, C.L.; Romanò, D.; Logoluso, N.; Drago, L. Bone and joint infections in adults: A comprehensive classification proposal. Eur. J. Orthop. Surg. Traumatol. 2011, 1, 207. [CrossRef] [PubMed]

32. Urish, K.L.; Cassat, J.E. Staphylococcus aureus osteomyelitis: Bone, bugs, and surgery. Infect. Immun. 2020, 88, e00932-19. [CrossRef]

33. Tsukasaki, M.; Takayanagi, H. Osteoimmunology: Evolving concepts in bone-immune interactions in health and disease. Nat. Rev. Immunol. 2019, 19, 626-642. [CrossRef] [PubMed] 
34. Cain, C.J.; Rueda, R.; McLelland, B.; Collette, N.M.; Loots, G.G.; Manilay, J.O. Absence of sclerostin adversely affects B-cell survival. J. Bone Miner. Res. 2012, 27, 1451-1461. [CrossRef]

35. Morrison, S.J.; Scadden, D.T. The bone marrow niche for haematopoietic stem cells. Nature 2014, 505, 327-334. [CrossRef]

36. Bravenboer, N.; Oostlander, A.E.; van Bodegraven, A.A. Bone loss in patients with inflammatory bowel disease: Cause, detection and treatment. Curr. Opin. Gastroenterol. 2021, 37, 128-134. [CrossRef] [PubMed]

37. Ojogun, N.; Barnstein, B.; Huang, B.; Oskeritzian, C.A.; Homeister, J.W.; Miller, D.; Ryan, J.J.; Carlyon, J.A. Anaplasma phagocytophilum infects mast cells via alpha1,3-fucosylated but not sialylated glycans and inhibits IgE-mediated cytokine production and histamine release. Infect. Immun. 2011, 79, 2717-2726. [CrossRef] [PubMed]

38. Granick, J.L.; Reneer, D.V.; Carlyon, J.A.; Borjesson, D.L. Anaplasma phagocytophilum infects cells of the megakaryocytic lineage through sialylated ligands but fails to alter platelet production. J. Med. Microbiol. 2018, 57, 416-423. [CrossRef]

39. Herron, M.J.; Ericson, M.E.; Kurtti, T.J.; Munderloh, U.G. The interactions of Anaplasma phagocytophilum, endothelial cells, and human neutrophils. Ann. N. Y. Acad. Sci. 2005, 1063, 374-382. [CrossRef]

40. Almazán, C.; Fourniol, L.; Rouxel, C.; Alberdi, P.; Gandoin, C.; Lagrée, A.C.; Boulouis, H.J.; de la Fuente, J.; Bonnet, S.I. Experimental Ixodes ricinus-Sheep Cycle of Anaplasma phagocytophilum NV2Os Propagated in Tick Cell Cultures. Front. Vet. Sci. 2020, 7, 40. [CrossRef]

41. Johns, J.L.; Discipulo, M.L.; Koehne, A.L.; Moorhead, K.A.; Nagamine, C.M. Influence of Genetic Background on Hematologic and Histopathologic Alterations during Acute Granulocytic Anaplasmosis in 129/SvEv and C57BL/6J Mice Lacking Type I and Type II Interferon Signaling. Comp. Med. 2017, 67, 127-137.

42. Tate, C.M.; Mead, D.G.; Luttrell, M.P.; Howerth, E.W.; Dugan, V.G.; Munderloh, U.G.; Davidson, W.R. Experimental infection of white-tailed deer with Anaplasma phagocytophilum, etiologic agent of human granulocytic anaplasmosis. J. Clin. Microbiol. 2005, 43, 3595-3601. [CrossRef] [PubMed]

43. Annen, K.; Friedman, K.; Eshoa, C.; Horowitz, M.; Gottschall, J.; Straus, T. Two cases of transfusion-transmitted Anaplasma phagocytophilum. Am. J. Clin. Pathol. 2012, 137, 562-565. [CrossRef] [PubMed]

44. Lewis, S.R.; Zimmerman, K.; Dascanio, J.J.; Pleasant, R.S.; Witonsky, S.G. Equine granulocytic anaplasmosis: A case report and review. J. Equine Vet. Sci. 2009, 29, 160-166. [CrossRef]

45. Uehlinger, F.D.; Clancey, N.P.; Lofstedt, J. Granulocytic anaplasmosis in a horse from Nova Scotia caused by infection with Anaplasma phagocytophilum. Can. Vet. J. 2011, 52, 537-540. [PubMed]

46. Khatat, S.E.; Culang, D.; Gara-Boivin, C. Granulocytic anaplasmosis in 2 dogs from Quebec. Can. Vet. J. $2018,59,663-667$.

47. Yi, J.; Kim, K.-H.; Ko, M.K.; Lee, E.Y.; Choi, S.J.; Oh, M.D. Human Granulocytic Anaplasmosis as a Cause of Febrile Illness in Korea Since at Least 2006. Am. J. Trop. Med. Hyg. 2017, 96, 777-782. [CrossRef]

48. Marko, D.; Perry, A.M.; Ponnampalam, A.; Nasr, M.R. Cytopenias and clonal expansion of gamma/delta T-cells in a patient with anaplasmosis: A potential diagnostic pitfall. J. Clin. Exp. Hematop. 2017, 56, 160-164. [CrossRef]

49. Stokes, W.; Lisboa, L.F.; Lindsay, L.R.; Fonseca, K. Case Report: Anaplasmosis in Canada: Locally Acquired Anaplasma phagocytophilum Infection in Alberta. Am. J. Trop. Med. Hyg. 2020, 103, 2478-2480. [CrossRef]

50. Jereb, M.; Pecaver, B.; Tomazic, J.; Muzlovic, I.; Avsic-Zupanc, T.; Premru-Srsen, T.; Levicnik-Stezinar, S.; Karner, P.; Strle, F. Severe human granulocytic anaplasmosis transmitted by blood transfusion. Emerg. Infect. Dis. 2012, 18, 1354-1357. [CrossRef] [PubMed]

51. Kim, S.W.; Kim, C.M.; Kim, D.M.; Yun, N.R. Manifestation of anaplasmosis as cerebral infarction: A case report. BMC Infect. Dis. 2018, 18, 409. [CrossRef]

52. Parkins, M.D.; Church, D.L.; Jiang, X.Y.; Gregson, D.B. Human granulocytic anaplasmosis: First reported case in Canada. Can. J. Infect. Dis. Med. Microbiol. 2009, 20, e100-e102. [CrossRef]

53. Borjesson, D.; Macnamara, K.; Johns, J.; Winslow, G. Anaplasma phagocytophilum and Ehrlichia muris induce cytopenias and global defects in hematopoiesis. Clin. Microbiol. Infect. 2009, 15, 66-67. [CrossRef] [PubMed]

54. Bexfield, N.H.; Villiers, E.J.; Herrtage, M.E. Immune-mediated haemolytic anaemia and thrombocytopenia associated with Anaplasma phagocytophilum in a dog. J. Small Anim. Pract. 2005, 46, 543-548. [CrossRef]

55. Klein, M.B.; Miller, J.S.; Nelson, C.M.; Goodman, J.L. Primary bone marrow progenitors of both granulocytic and monocytic lineages are susceptible to infection with the agent of human granulocytic ehrlichiosis. J. Infect. Dis. 1997, 176, 1405-1409. [CrossRef] [PubMed]

56. Klein, M.B.; Hu, S.; Chao, C.C.; Goodman, J.L. The agent of human granulocytic ehrlichiosis induces the production of myelosuppressing chemokines without induction of proinflammatory cytokines. J. Infect. Dis. 2000, 182, 200-205. [CrossRef]

57. Rikihisa, Y. Mechanisms of obligatory intracellular infection with Anaplasma phagocytophilum. Clin. Microbiol. Rev. 2011, 24, 469-489. [CrossRef]

58. Cohen, S.B.; Yabsley, M.J.; Freye, J.D.; Dunlap, B.G.; Rowland, M.E.; Huang, J.; Dunn, J.R.; Jones, T.F.; Moncayo, A.C. Prevalence of Ehrlichia chaffeensis and Ehrlichia ewingii in ticks from Tennessee. Vector Borne Zoonotic Dis. 2010, 10, 435-440. [CrossRef]

59. Pritt, B.S.; Allerdice, M.E.J.; Sloan, L.M.; Paddock, C.D.; Munderloh, U.G.; Rikihisa, Y.; Tajima, T.; Paskewitz, S.M.; Neitzel, D.F.; Hoang Johnson, D.K.; et al. Proposal to reclassify Ehrlichia muris as Ehrlichia muris subsp. muris subsp. nov. and description of Ehrlichia muris subsp. eauclairensis subsp. nov., a newly recognized tick-borne pathogen of humans. Int. J. Syst. Evol. Microbiol. 2017, 67, 2121-2126. [CrossRef] [PubMed]

60. Ismail, N.; Bloch, K.C.; McBride, J.W. Human ehrlichiosis and anaplasmosis. Clin. Lab. Med. 2010, 30, 261-292. [CrossRef] [PubMed] 
61. Olano, J.P.; Masters, E.; Hogrefe, W.; Walker, D.H. Human monocytotropic ehrlichiosis, Missouri. Emerg. Infect. Dis. 2003, 9, 1579-1586. [CrossRef] [PubMed]

62. Dubie, T.; Mohammed, Y.; Terefe, G.; Muktar, Y.; Tesfaye, J. An insight review on canine ehrlichiosis with emphasis on its epidemiology and pathogenesity importance. Glob. J. Vet. Med. Res. 2014, 2, 59-67.

63. Al-Badrani, B.A. Diagnostic study of ehrlichiosis in cattle of Mosul-Iraq. Bas. J. Vet. Res. 2013, 12, 87-97. [CrossRef]

64. Saito, T.B.; Thirumalapura, N.R.; Shelite, T.R.; Rockx-Brouwer, D.; Popov, V.L.; Walker, D.H. An animal model of a newly emerging human ehrlichiosis. J. Infect. Dis. 2015, 211, 452-461. [CrossRef] [PubMed]

65. Allen, M.B.; Pritt, B.S.; Sloan, L.M.; Paddock, C.D.; Musham, C.K.; Ramos, J.M.; Cetin, N.; Rosenbaum, E.R. First reported case of Ehrlichia ewingii involving human bone marrow. J. Clin. Microbiol. 2014, 52, 4102-4104. [CrossRef] [PubMed]

66. Qurollo, B.A.; Buch, J.; Chandrashekar, R.; Beall, M.J.; Breitschwerdt, E.B.; Yancey, C.B.; Caudill, A.H.; Comyn, A. Clinicopathological findings in 41 dogs (2008-2018) naturally infected with Ehrlichia ewingii. J. Vet. Intern. Med. 2019, 33, 618-629. [CrossRef] [PubMed]

67. Tan, H.P.; Dumler, J.S.; Maley, W.R.; Klein, A.S.; Burdick, J.F.; Fred Poordad, F.; Thuluvath, P.J.; Markowitz, J.S. Human monocytic ehrlichiosis: An emerging pathogen in transplantation. Transplantation 2001, 71, 1678-1680. [CrossRef] [PubMed]

68. MacNamara, K.C.; Racine, R.; Chatterjee, M.; Borjesson, D.; Winslow, G.M. Diminished hematopoietic activity associated with alterations in innate and adaptive immunity in a mouse model of human monocytic ehrlichiosis. Infect. Immun. 2009, 77, 4061-4069. [CrossRef]

69. Smith, J.N.P.; Zhang, Y.; Li, J.J.; McCabe, A.; Jo, H.J.; Maloney, J.; MacNamara, K.C. Type I IFNs drive hematopoietic stem and progenitor cell collapse via impaired proliferation and increased RIPK1-dependent cell death during shock-like ehrlichial infection. PLoS Pathog. 2018, 14, e1007234. [CrossRef]

70. Dumler, J.S.; Dawson, J.E.; Walker, D.H. Human ehrlichiosis: Hematopathology and immunohistologic detection of Ehrlichia chaffeensis. Hum Pathol. 1993, 24, 391-396. [CrossRef]

71. Vannier, E.G.; Diuk-Wasser, M.A.; Ben, M.C.; Krause, P.J. Babesiosis. Infect. Dis. Clin. N. Am. 2015, 29, 357-370. [CrossRef]

72. Joseph, J.T.; Roy, S.S.; Shams, N.; Visintainer, P.; Nadelman, R.B.; Hosur, S.; Nelson, J.; Wormser, G.P. Babesiosis in Lower Hudson Valley, New York, USA. Emerg. Infect. Dis. 2011, 17, 843-847. [CrossRef]

73. Orinda, G.O.; Commins, M.A.; Waltisbuhl, D.J.; Goodger, B.V.; Wright, I.G. A study of autoantibodies to phosphatidyl-serine in Babesia bovis and Babesia bigemina infections in cattle. Vet. Immunol. Immunopathol. 1994, 40, 275-281. [CrossRef]

74. Bhanot, P.; Parveen, N. Investigating disease severity in an animal model of concurrent babesiosis and Lyme disease. Int. J. Parasitol. 2019, 49, 145-151. [CrossRef] [PubMed]

75. Lewis, D.C.; Meyers, K.M.; Callan, M.B.; Bücheler, J.; Giger, U. Detection of platelet-bound and serum platelet-bindable antibodies for diagnosis of idiopathic thrombocytopenic purpura in dogs. J. Am. Vet. Med. Assoc. 1995, 206, 47-52.

76. Huang, S.; Zhang, L.; Yao, L.; Li, J.; Chen, H.; Ni, Q.; Pan, C.; Jin, L. Human babesiosis in Southeast China: A case report. Int. J. Infect. Dis. 2018, 68, 36-38. [CrossRef] [PubMed]

77. Man, S.Q.; Qiao, K.; Cui, J.; Feng, M.; Fu, Y.F.; Cheng, X.J. A case of human infection with a novel Babesia species in China. Infect. Dis. Poverty 2016, 5, 28. [CrossRef]

78. Zhao, L.; Jiang, R.; Jia, N.; Ning, N.; Zheng, Y.; Huo, Q.; Sun, Y.; Yuan, T.; Jiang, B.; Li, T.; et al. Human Case Infected with Babesia venatorum: A 5-Year Follow-Up Study. Open Forum Infect. Dis. 2020, 7, ofaa062. [CrossRef]

79. Clark, I.A.; Jacobson, L.S. Do babesiosis and malaria share a common disease process? Ann. Trop. Med. Parasitol. 1998, 92, 483-488. [CrossRef]

80. Orf, K.; Cunnington, A.J. Infection-related hemolysis and susceptibility to Gram-negative bacterial co-infection. Front Microbiol. 2015, 6, 666. [CrossRef] [PubMed]

81. Scheepers, E.; Leisewitz, A.L.; Thompson, P.N.; Christopher, M.M. Serial haematology results in transfused and non-transfused dogs naturally infected with Babesia rossi. J. S. Afr. Vet Assoc. 2011, 82, 136-143. [CrossRef]

82. Akel, T.; Mobarakai, N. Hematologic manifestations of babesiosis. Ann. Clin. Microbiol. Antimicrob. 2017, 16, 6. [CrossRef]

83. Bullard, J.M.; Ahsanuddin, A.N.; Perry, A.M.; Lindsay, L.R.; Iranpour, M.; Dibernardo, A.; Van Caeseele, P.G. The first case of locally acquired tick-borne Babesia microti infection in Canada. Can. J. Infect. Dis. Med. Microbiol. 2014, 25, e87-e89. [CrossRef] [PubMed]

84. Hovius, K.E.; Rijpkema, S.G.; Westers, P.; van der Zeijst, B.A.; van Asten, F.J.; Houwers, D.J. A serological study of cohorts of young dogs, naturally exposed to Ixodes ricinus ticks, indicates seasonal reinfection by Borrelia burgdorferi sensu lato. Vet. $Q$. 1999, 21, 16-20. [CrossRef]

85. Cleveland, C.A.; Swanepoel, L.; Brown, J.D.; Casalena, M.J.; Williams, L.; Yabsley, M.J. Surveillance for Borrelia spp. in Upland Game Birds in Pennsylvania, USA. Vet. Sci. 2020, 7, 82. [CrossRef]

86. Tang, T.T.; Zhang, L.; Bansal, A.; Grynpas, M.; Moriarty, T.J. The Lyme Disease Pathogen Borrelia burgdorferi Infects Murine Bone and Induces Trabecular Bone Loss. Infect. Immun. 2017, 85, e00781-16. [CrossRef] [PubMed]

87. Oksi, J.; Mertsola, J.; Reunanen, M.; Marjamäki, M.; Viljanen, M.K. Subacute multiple-site osteomyelitis caused by Borrelia burgdorferi. Clin. Infect. Dis. 1994, 19, 891-896. [CrossRef]

88. Steere, A.C.; Schoen, R.T.; Taylor, E. The clinical evolution of Lyme arthritis. Ann. Intern. Med. 1987, 107, 725-731. [CrossRef]

89. Schlesinger, P.A.; Duray, P.H.; Burke, B.A.; Steere, A.C.; Stillman, M.T. Maternal-fetal transmission of the Lyme disease spirochete, Borrelia burgdorferi. Ann. Intern. Med. 1985, 103, 67-68. [CrossRef] [PubMed] 
90. Houtman, P.M.; Tazelaar, D.J. Joint and bone involvement in Dutch patients with Lyme borreliosis presenting with acrodermatitis chronica atrophicans. Neth. J. Med. 1999, 54, 5-9. [CrossRef]

91. Hovmark, A.; Asbrink, E.; Olsson, I. Joint and bone involvement in Swedish patients with Ixodes ricinus-borne Borrelia infection. Zentralbl. Bakteriol. Mikrobiol. Hyg. A 1986, 263, 275-284. [PubMed]

92. Kvasnicka, H.M.; Thiele, J.; Ahmadi, T. Bone marrow manifestation of Lyme disease (Lyme borreliosis). Br. J. Haematol. 2003, 120, 723. [CrossRef] [PubMed]

93. Lawson, J.P.; Rahn, D.W. Lyme disease and radiologic findings in Lyme arthritis. AJR Am. J. Roentgenol. 1992, 158, 1065-1069. [CrossRef] [PubMed]

94. Lawson, J.P.; Steere, A.C. Lyme arthritis: Radiologic findings. Radiology 1985, 154, 37-43. [CrossRef] [PubMed]

95. Munson, E.; Nardelli, D.T.; Du-Chateau, B.K.; Callister, S.M.; Schell, R.F. Hamster and murine models of severe destructive Lyme arthritis. Clin. Dev. Immunol. 2012, 2012, 504215. [CrossRef] [PubMed]

96. Schmitz, G.; Vanhoenacker, F.M.; Gielen, J. Unusual musculoskeletal manifestations of Lyme disease. JBR-BTR 2004, 87, 224-228.

97. Steere, A.C. Musculoskeletal manifestations of Lyme disease. Am. J. Med. 1995, 98, 44S-48S. [CrossRef]

98. Zlotnikov, N.; Javid, A.; Ahmed, M.; Eshghi, A.; Tang, T.T.; Arya, A.; Bansal, A.; Matar, F.; Parikh, M.; Ebady, R.; et al. Infection with the Lyme disease pathogen suppresses innate immunity in mice with diet-induced obesity. Cell. Microbiol. 2017, 19, e12689. [CrossRef] [PubMed]

99. Isogai, E.; Isogai, H.; Kimura, K.; Hayashi, S.; Kubota, T.; Nishikawa, T.; Nakane, A.; Fujii, N. Cytokines in the serum and brain in mice infected with distinct species of Lyme disease Borrelia. Microb. Pathog. 1996, 21, 413-419. [CrossRef]

100. Redlich, K.; Smolen, J.S. Inflammatory bone loss: Pathogenesis and therapeutic intervention. Nat. Rev. Drug Discov. 2012, 11, 234-250. [CrossRef]

101. Kosoy, O.I.; Lambert, A.J.; Hawkinson, D.J.; Pastula, D.M.; Goldsmith, C.S.; Hunt, D.C.; Staples, J.E. Novel thogotovirus associated with febrile illness and death, United States, 2014. Emerg. Infect. Dis. 2015, 21, 760-764. [CrossRef] [PubMed]

102. Bricker, T.L.; Shafiuddin, M.; Gounder, A.P.; Janowski, A.B.; Zhao, G.; Williams, G.D.; Jagger, B.W.; Diamond, M.S.; Bailey, T.; Kwon, J.H.; et al. Therapeutic efficacy of favipiravir against Bourbon virus in mice. PLoS Pathog. 2019, 15, e1007790. [CrossRef]

103. Pace, E.J.; O'Reilly, M. Tickborne Diseases: Diagnosis and Management. Am. Fam. Physician 2020, 101, 530-540.

104. Burgdorfer, W. Colorado tick fever. II. The behavior of Colorado tick fever virus in rodents. J. Infect. Dis. 1960, 107, 384-388. [CrossRef]

105. Bowen, G.S.; Shriner, R.B.; Pokorny, K.S.; Kirk, L.J.; McLean, R.G. Experimental Colorado tick fever virus infection in Colorado mammals. Am. J. Trop. Med. Hyg. 1981, 30, 224-229. [CrossRef]

106. Kadkhoda, K.; Semus, M.; Jelic, T.; Walkty, A. Case Report: A case of colorado tick fever acquired in Southwestern Saskatchewan. Am. J. Trop. Med. Hyg. 2018, 98, 891-893. [CrossRef]

107. Centers for Disease Control and Prevention. Available online: https://www.cdc.gov/coloradotickfever/faqs.html (accessed on 1 March 2021).

108. Oshiro, L.S.; Dondero, D.V.; Emmons, R.W.; Lennette, E.H. The development of Colorado tick fever virus within cells of the haemopoietic system. J. Gen. Virol. 1978, 39, 73-79. [CrossRef]

109. Emmons, R.W.; Oshiro, L.S.; Johnson, H.N.; Lennette, E.H. Intra-erythrocytic location of Colorado tick fever virus. J. Gen. Virol. 1972, 17, 185-195. [CrossRef] [PubMed]

110. Philipp, C.S.; Callaway, C.; Chu, M.C.; Huang, G.H.; Monath, T.P.; Trent, D.; Evatt, B.L. Replication of Colorado tick fever virus within human hematopoietic progenitor cells. J. Virol. 1993, 67, 2389-2395. [CrossRef] [PubMed]

111. AbuSamra, D.B.; Aleisa, F.A.; Al-Amoodi, A.S.; Jalal Ahmed, H.M.; Chin, C.J.; Abuelela, A.F.; Bergam, P.; Sougrat, R.; Merzaban, J.S. Not just a marker: CD34 on human hematopoietic stem/progenitor cells dominates vascular selectin binding along with CD44. Blood Adv. 2017, 1, 2799-2816. [CrossRef] [PubMed]

112. Emmons, R.W. Colorado tick fever along the Pacific slope of North America. Jap. J. Med. Sci. Biol. 1967, 20, 166-170. [PubMed]

113. Government of Canada, Diseases and Conditions. Available online: https://www.canada.ca/en/public-health/services/ diseases/tick-borne-encephalitis/causes-tick-borne-encephalitis.html (accessed on 1 March 2021).

114. Barp, N.; Trentini, A.; Di-Nuzzo, M.; Mondardini, V.; Francavilla, E.; Contini, C. Clinical and laboratory findings in tick-borne encephalitis virus infection. Parasite Epidemiol. Control. 2020, 10, e00160. [CrossRef] [PubMed]

115. Bogovic, P.; Strle, F. Tick-borne encephalitis: A review of epidemiology, clinical characteristics, and management. World J. Clin. Cases 2015, 3, 430-441. [CrossRef] [PubMed]

116. Lotric-Furlan, S.; Strle, F. Thrombocytopenia-a common finding in the initial phase of tick-borne encephalitis. Infection 1995, 23, 203-206. [CrossRef] [PubMed]

117. Lotric-Furlan, S.; Strle, F. Thrombocytopenia, leukopenia and abnormal liver function tests in the initial phase of tick-borne encephalitis. Zentralbl. Bakteriol. 1995, 282, 275-278. [CrossRef]

118. Bühler, T.; Boos, N.; Leuppi-Taegtmeyer, A.B.; Berger, C.T. Febrile illness and bicytopenia within hours after tick-borne encephalitis booster vaccination. NPJ Vaccines 2019, 4, 52. [CrossRef]

119. Ruzek, J.S.D. Tick-borne encephalitis in domestic animals. Acta Virol. 2020, 64, 223-229.

120. Wilhelmsson, P.; Jaenson, T.G.T.; Olsen, B.; Waldenström, J.; Lindgren, P.E. Migratory birds as disseminators of ticks and the tick-borne pathogens Borrelia bacteria and tick-borne encephalitis (TBE) virus: A seasonal study at Ottenby Bird Observatory in South-eastern Sweden. Parasites Vectors 2020, 13, 607. [CrossRef] 
121. Mansfield, K.L.; Johnson, N.; Phipps, L.P.; Stephenson, J.R.; Fooks, A.R.; Solomon, T. Tick-borne encephalitis virus-A review of an emerging zoonosis. J. Gen. Virol. 2009, 90, 1781-1794. [CrossRef]

122. Růžek, D.; Dobler, G.; Mantke, O.D. Tick-borne encephalitis: Pathogenesis and clinical implications. Travel Med. Infect. Dis. 2010, 8, 223-232. [CrossRef]

123. Whitehouse, C.A. Crimean-Congo hemorrhagic fever. Antivir. Res. 2004, 64, 145-160. [CrossRef] [PubMed]

124. Ergonul, O. Crimean-Congo hemorrhagic fever virus: New outbreaks, new discoveries. Curr. Opin. Virol. 2012, 2, 215-220. [CrossRef] [PubMed]

125. Aksoy, D.; Barut, H.; Duygu, F.; Çevik, B.; Kurt, S.; Sümbül, O. Characteristics of headache and its relationship with disease severity in patients with Crimean-Congo hemorrhagic fever. Agri 2018, 30, 12-17. [CrossRef] [PubMed]

126. Peyrefitte, C.; Marianneau, P.; Tordo, N.; Bouloy, M. Crimean-Congo haemorrhagic fever. Rev. Sci. Tech. 2015, 34, 391-401. [CrossRef]

127. Bente, D.A.; Alimonti, J.B.; Shieh, W.J.; Camus, G.; Ströher, U.; Zaki, S.; Jones, S.M. Pathogenesis and immune response of Crimean-Congo hemorrhagic fever virus in a STAT-1 knockout mouse model. J. Virol. 2010, 84, 11089-11100. [CrossRef] [PubMed]

128. Cross, R.W.; Prasad, A.N.; Borisevich, V.; Geisbert, J.B.; Agans, K.N.; Deer, D.J.; Fenton, K.A.; Geisbert, T.W. Crimean-Congo hemorrhagic fever virus strains Hoti and Afghanistan cause viremia and mild clinical disease in cynomolgus monkeys. PLoS Negl. Trop. Dis. 2020, 14, e0008637. [CrossRef]

129. Swanepoel, R.; Gill, D.E.; Shepherd, A.J.; Leman, P.A.; Mynhardt, J.H.; Harvey, S. The clinical pathology of Crimean-Congo hemorrhagic fever. Rev. Infect. Dis. 1989, 11, S794-S800. [CrossRef]

130. Cagatay, A.; Kapmaz, M.; Karadeniz, A.; Basaran, S.; Yenerel, M.; Yavuz, S.; Midilli, K.; Ozsut, H.; Eraksoy, H.; Calangu, S. Haemophagocytosis in a patient with Crimean Congo haemorrhagic fever. J. Med. Microbiol. 2007, 56, 1126-1128. [CrossRef]

131. Fisgin, N.T.; Fisgin, T.; Tanyel, E.; Doganci, L.; Tulek, N.; Guler, N.; Duru, F. Crimean-Congo hemorrhagic fever: Five patients with hemophagocytic syndrome. Am. J. Hematol. 2008, 83, 73-76. [CrossRef]

132. Morimoto, A.; Nakazawa, Y.; Ishii, E. Hemophagocytic lymphohistiocytosis: Pathogenesis, diagnosis, and management. Pediatr. Int. 2016, 58, 817-825. [CrossRef] 